\title{
Contribution to the knowledge of the genus Calliclytus Fisher, 1932 (Coleoptera: Cerambycidae: Cerambycinae: Tillomorphini), with a new synonymy and description of a new species from the Dominican Republic
}

\author{
К познанию жкуков-дровосеков рода Calliclytus Fisher, 1932 \\ (Coleoptera: Cerambycidae: Cerambycinae: Tillomorphini) \\ с новой синонимией и описанием нового вида \\ из Аоминиканской Респубцики
}

\author{
Alexandr I. Miroshnikov ${ }^{1,2}$ \\ А.И. Мирошников ${ }^{1,2}$
}

\footnotetext{
${ }^{1}$ Russian Entomological Society, Krasnodar, Russia. E-mail: miroshnikov-ai@yandex.ru.

2 Sochi National Park, Moskovskaya str. 21, Sochi, Krasnodar region 354002, Russia.

${ }^{1}$ Русское энтомологическое общество, Краснодар, Россия.

2 Сочинский национальный парк, ул. Московская 21, Сочи, Краснодарский край 354002, Россия.
}

KEY WORDS: Coleoptera, Cerambycidae, Tillomorphini, Calliclytus, new synonymy, key to species, new species, Dominican Republic.

КЛЮЧЕВЫЕ СЛОВА: Coleoptera, Cerambycidae, Tillomorphini, Calliclytus, новая синонимия, определительная таблица видов, новый вид, Доминиканская Республика.

ABSTRACT. A brief review of the genus Calliclytus Fisher, 1932, as well as a key to its species are given. The following new synonymy is established: Calliclytus Fisher, 1932 = Lamproclytus Fisher, 1932, syn.n. A new species, C. wappesi sp.n., is described from the Dominican Republic. It is most similar to $C$. macoris Lingafelter, 2011, but differs clearly in the almost entirely black coloration of the elytra, the peculiar sculpture of the pro- and mesosternum, the narrower mesosternal process, and some other traits. The following new combination is established: Calliclytus elegans (Fisher, 1932), comb.n. Abundant colour pictures, including the type specimens of all studied species, are presented.

РЕЗЮМЕ. Представлен краткий обзор рода Calliclytus Fisher, 1932. Дана таблица для определения его видов. Установлена следующая новая синонимия: Calliclytus Fisher, 1932 = Lamproclytus Fisher, 1932, syn.n. Описан новый вид $C$. wappesi sp.n. из Доминиканской Республики. Он наиболее сходен с C. macoris Lingafelter, 2011, но ясно отличается почти целиком черной окраской надкрылий, своеобразной скульптурой про- и мезостернума, более узким отростком мезостернума и некоторыми други- ми признаками. Установлена следующая новая комбинация: Calliclytus elegans (Fisher, 1932), comb.n. Представлено большое количество цветных иллюстраций, в том числе типовых экземпляров всех исследуемых видов.

\section{Introduction}

The genus Calliclytus Fisher, 1932 was established for a single species, C. schwarzi Fisher, 1932, from Cuba [Fisher, 1932]. The second species, Puerto Rican C. macoris Lingafelter, 2011, was described only relatively recently [Lingafelter, 2011]. Until now, the composition of this genus has remained unchanged.

Comparative morphological analysis of the genus Calliclytus and the very similar monotypic genus Lamproclytus Fisher, 1932, which begun by Lingafelter [2011], showed that the latter should be synonymised under the former genus.

In addition, a detailed study of the Lamproclytus specimen from the Dominican Republic, previously considered as L. elegans Fisher, 1932 [Miroshnikov, 2014], revealed that it is actually a new species of the genus Calliclytus, which is described in this paper.

How to cite this article: Miroshnikov A.I. 2020. Contribution to the knowledge of the genus Calliclytus Fisher, 1932 Coleoptera, Cerambycidae: Cerambycinae: Tillomorphini), with a new synonymy and description of a new species from the Dominican Republic // Russian Entomol. J. Vol.29. No.3. P.261-270. doi: 10.15298/rusentj.29.3.04 
The material used in this paper comes from the following institutional collections:

EMEC — Essig Museum of Entomology, University of California (Berkeley, California, USA);

USNM - National Museum of Natural History, Smithsonian Institution (Washington D.C., USA).

Genus Calliclytus Fisher, 1932

Calliclytus Fisher, 1932: 65. Blackwelder, 1946: 583; Zayas, 1975: 146; Monné, 1993: 73; Monné, Giesbert, 1995: 123; Peck, 2005: 173; Monné, 2005: 542; Monné, Hovore, 2005: 132; Monné et al, 2007: 138; Monné, Bezark, 2011: 169; Peck, Perez-Gelabert, 2012: 21; Monné, 2012: 52; Bezark, Monné, 2013: 174; Bezark, 2016: 177; Monné, 2020: 815 .

Lamproclytus Fisher, 1932: 67, syn.n. (type species: Lamproclytus elegans Fisher, 1932, by original designation); Blackwelder, 1946: 583; Monné, 1993: 73; Monné, Giesbert, 1995: 124; Monné, 2005: 552; Monné, Hovore, 2005: 134; Monné et al, 2007: 140; Micheli, 2010: 136; Monné, Bezark, 2011: 171; Monné, 2012: 53; Peck, Perez-Gelabert, 2012: 21; Bezark, Monné, 2013: 176; Bezark, 2016: 179; Monné, 2020: 827

Type species: Calliclytus schwarzi Fisher, 1932, by original designation.

COMPOSITION. The genus includes four species, one of which is described as new.

DISTRIBUTION. West Indies.

REMARKS. Lingafelter [2011: 63-66], while describing Calliclytus macoris, noted the following: "The genera Lamproclytus and Calliclytus were not specifically compared to each other in Fisher's [1932] descriptions, despite their obvious similarities in nearly every feature. Careful phylogenetic work in Tillomorphini may suggest that synonymy of these genera is necessary, but that is beyond the scope of this work. Given that the position of the eburneous elytral ridge of $C$. macoris is closest to that of $C$. schwarzi, it is placed in that genus as opposed to Lamproclytus.".

As a result of the detailed study of all the species presented in this work and taking into account the morphological features of a new species described here, I support the Lingafelter's conclusions and believe it is necessary to establish the following new synonymy: Calliclytus Fisher, $1932=$ Lamproclytus Fisher, 1932, syn.n.

In addition, one should pay attention to the very high degree of morphological similarity of the genera Calliclytus and Bonfilsia Villiers, 1979 and the correctness of the generic status of the latter, but that is beyond the scope of this paper.

Calliclytus schwarzi Fisher, 1932

Figs 1, 4, 7, 23, 25, 29.

Calliclytus schwarzi Fisher, 1932: 66. Type locality: Cuba, Cayamas (according to the original description and the label of the holotype). Blackwelder, 1946: 583; Zayas, 1975: 146, 372, pl. 19 , fig. d; Chemsak et al., 1992: 72; Monné, 1993: 73; Monné, Giesbert, 1995: 123; Monné, 2005: 543; Monné, Hovore, 2005: 132; Peck, 2005: 173; Monné et al, 2007: 139; Monné, Bezark, 2011: 169; Bezark, Monné, 2013: 174; Lingafelter et al., 2014: 316, figs 150, k, 1 (holotype); Devesa et al., 2015: 302 (figs 1-2), 303 (figs 3-5); Bezark, 2016: 177; Monné, 2020: 815.

MATERIAL. Holotype ơ (USNM) (Figs 1, 4, 7), "Cuba, Cayamas, 10.5 [1903]", "EA Schwarz Collector", "Calliclytus schwarzi Fisher", "Type No. 43744 U.S.N.M.” (Fig. 29); 1 ㅇ (EMEC) (photograph), Cuba [see Devesa et al., 2015: 302-303].

DISTRIBUTION. Cuba.

Calliclytus macoris Lingafelter, 2011

Figs 2, 5, 8, 10, 21, 26, 32.

Calliclytus macoris Lingafelter, 2011: 63. Type locality: R. Dominicana, $12 \mathrm{~km}$ W San Pedro de Macoris (according to the original description and the label of the holotype). Bezark, Monné, 2013: 174; Lingafelter et al., 2014: 94, figs 103 m, n (holotype) ); Bezark, 2016: 177; Monné, 2020: 815.

MATERIAL. Holotype 9 (USNM) (Figs 2, 5, 8), "R. Dominicana, $12 \mathrm{~km}$ W San Pedro de Macoris, May 5-19, 1985, E. Giesbert coll.", "Holotype + Calliclytus macoris Lingafelter Designated 2010" (Fig. 32).

$$
\text { DISTRIBUTION. Dominican Republic. }
$$

Calliclytus wappesi Miroshnikov, sp.n.

$$
\text { Figs 3, 6, 9, 11, } 22 .
$$

Lamproclytus elegans (non Fisher, 1932): Miroshnikov, 2014: 202 , figs $7-9$.

? Lamproclytus elegans (non Fisher, 1932): Monné, Giesbert, 1995: 124; (R Dominicana); Monné, Hovore, 2005: 134 (R Dominicana); Monné et al, 2007: 140 (R Dominicana); Monné, Bezark, 2011: 171 (R Dominicana); Bezark, Monné, 2013: 176 (R Dominicana); Bezark, 2016: 179 (Dominican Republic).

MATERIAL. Holotype + (USNM) (Figs 3, 6, 9), Dominican Republic, San Pedro Prov., Juan Dolio env., 13.V.1985, leg. J.E. Wappes, "Lamproclytus oakleyi Fish. Det J.E. Wappes".

DIAGNOSIS. The new species is most similar to $C$. macoris, but differs distinctly by the entirely black coloration of the elytra (excluding an eburneous fascia and a brownish apical spot at the suture) and head, as in Figs 3, 6, 9 (cf. Figs $2,5,8)$; the more curved eburneous fascia on each elytron, especially when viewed from the side, as in Fig. 9 (cf. Fig. 8); the clearly more numerous, rough, irregular punctures on the prosternum, as in Fig. 22 (cf. Fig. 21), the less sharp border between the scabrous and smoothened sculpture in its apical one fourth, as indicated by arrows in Fig. 22 (cf. Fig. 21); the presence of coarse sculpture on the mesosternum, partly in the form of irregular grooves; the narrower mesosternal process with a more narrow emargination apically, as in Fig. 11 (cf. Fig. 10). Calliclytus wappesi sp.n. can also be compared to C. schwarzi, but is distinguished through, like from C. macoris, the almost entirely black coloration of the elytra, as in Figs 3, 9 (cf. Figs 1, 7), in addition, the black coloration of the pronotum (almost entirely), femora, tibiae, and venter, as in Figs 3, 6, 9 (cf. Figs 1, 4, 7), as well as by the entirely alveolate-punctate pronotal disc, the somewhat different shape of the eburneous fascia on each elytron, being the less narrowed towards the suture, as in Fig. 3 (cf. Fig. 1), the presence of yellow, erect, very long setae in addition to white setae on the pronotum and elytra (like in C.macoris), and some other traits. In addition, the new species differs very clearly from Calliclytus elegans comb.n. by the location of the eburneous fascia on each elytron, as in Figs 3, 9 (cf. Figs 12-14, 18-20), the almost entirely black coloration of the elytra, like from $C$. macoris and C. schwarzi, as in Figs 3, 9 (cf. Figs 12-14, 1820 ), the black coloration of the femora, tibiae and venter, as in Figs 3, 6, 9 (cf. Figs 12-20), and some other traits. See also the Key below.

DESCRIPTION. Female (see Remarks below). Body length $3.95 \mathrm{~mm}$, humeral width $1.05 \mathrm{~mm}$. Body (almost entirely), femora and tibiae black; most mouthparts, genae, most of antennomeres starting from scape, very base and very apex of pronotum, abdominal apex, procoxae and protrochanters, partly, tarsomeres 3 and 4 reddish brown; elytral fascia eburneous (ivory), whereas apical spot near suture of elytra brownish; apical antennomeres, tarsomeres 1 and 2 dark brown.

Body, antennae and legs with long or very long, erect, light setae, but ones on pronotum and elytra yellow and white tones, whereas on remaining parts only white (like in $C$. macoris); in addition, pronotum with suberect and partly erect, shorter, white setae. 


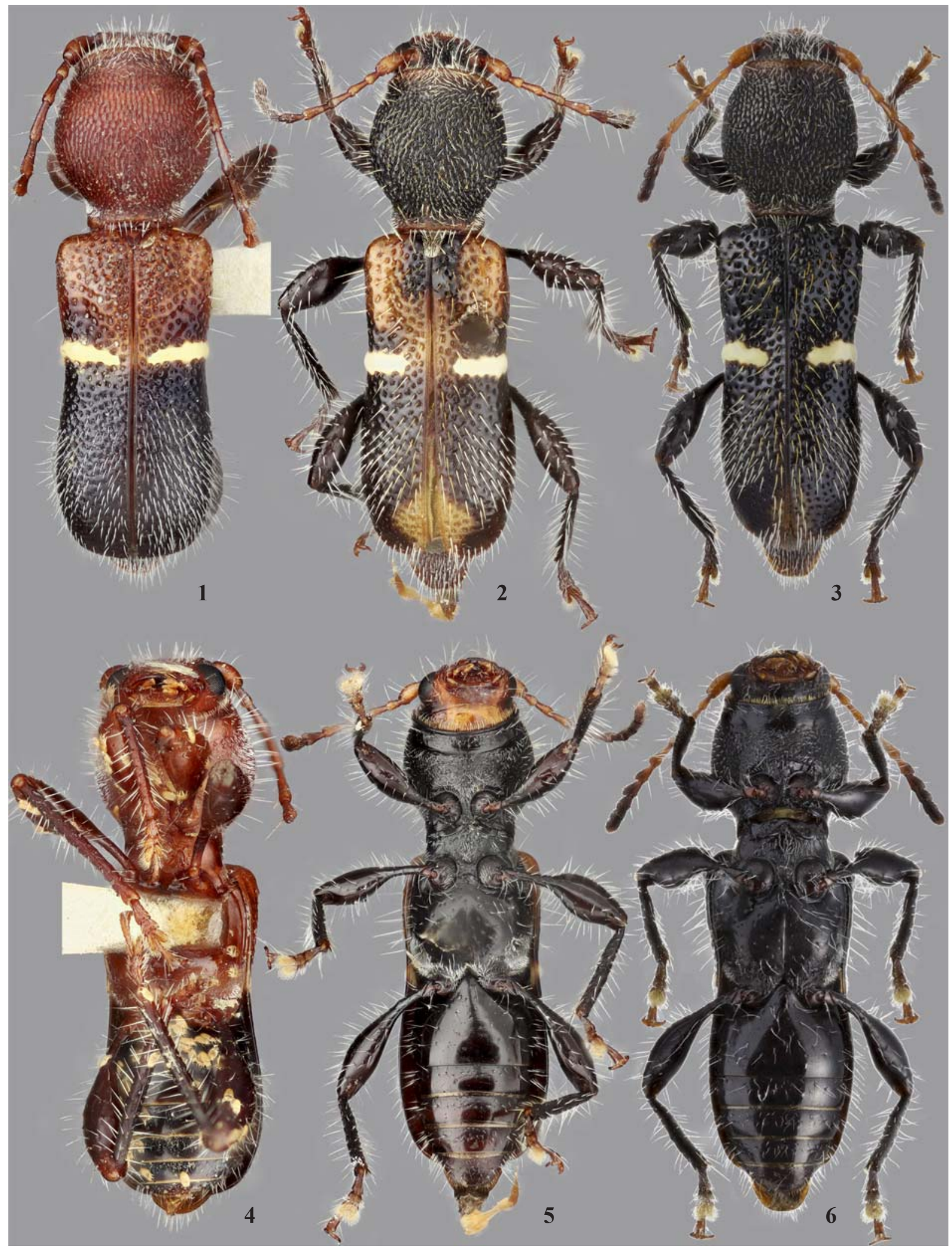

Figs 1-6. Calliclytus spp., holotypes, habitus, dorsal and ventral views: 1, $4-$ C. schwarzi, male; 2, 5-C. macoris, female; 3, $6-$ C. wappesi sp.n., female (1-2, 4-5 - photographs by Alexander Konstantinov).

Рис. 1-6. Calliclytus spp., голотипы, общий вид, сверху и снизу: 1, $4-$ C. schwarzi, самец; 2, 5-C. macoris, самка; $3,6-C$. wappesi sp.n. , самка (1-2, 4-5 - фотографии А. Константинова). 


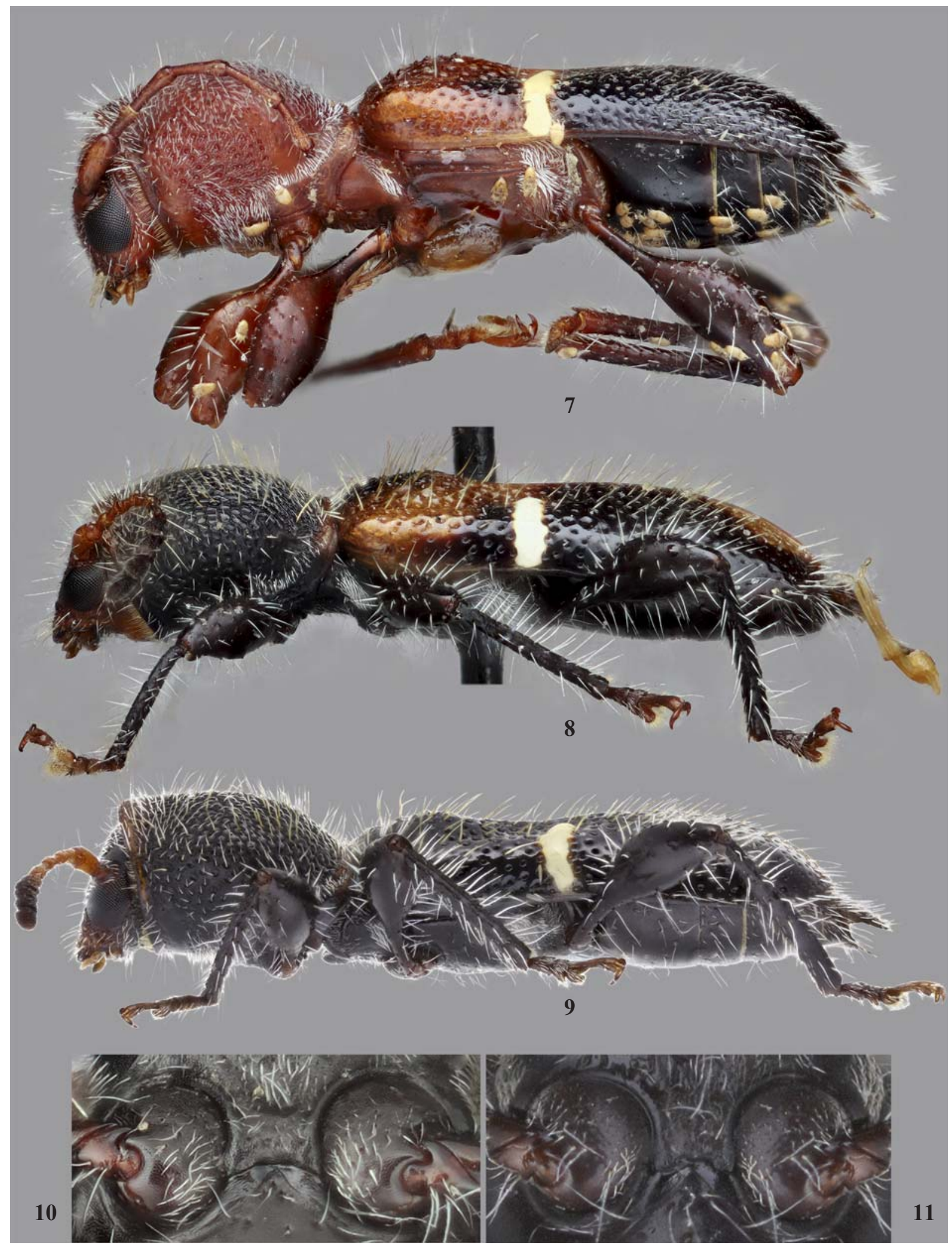

Figs 7-11. Calliclytus spp., holotypes: $7-$ C. schwarzi, male; 8, $10-$ C. macoris, female; 9, $11-$ C. wappesi sp.n., female; 7-9habitus, lateral view; $10-11-$ mesosternal process $(7-8,10-$ photographs by Alexander Konstantinov).

Рис. 7-11. Calliclytus spp., голотипы: $7-$ C. schwarzi, самец; 8, $10-$ C. macoris, самка; 9, $11-$ C. wappesi sp.n. , самка; 7-9 общий вид, сбоку; 10-11 - отросток мезостернума (7-8, 10 - фотографии А. Константинова). 


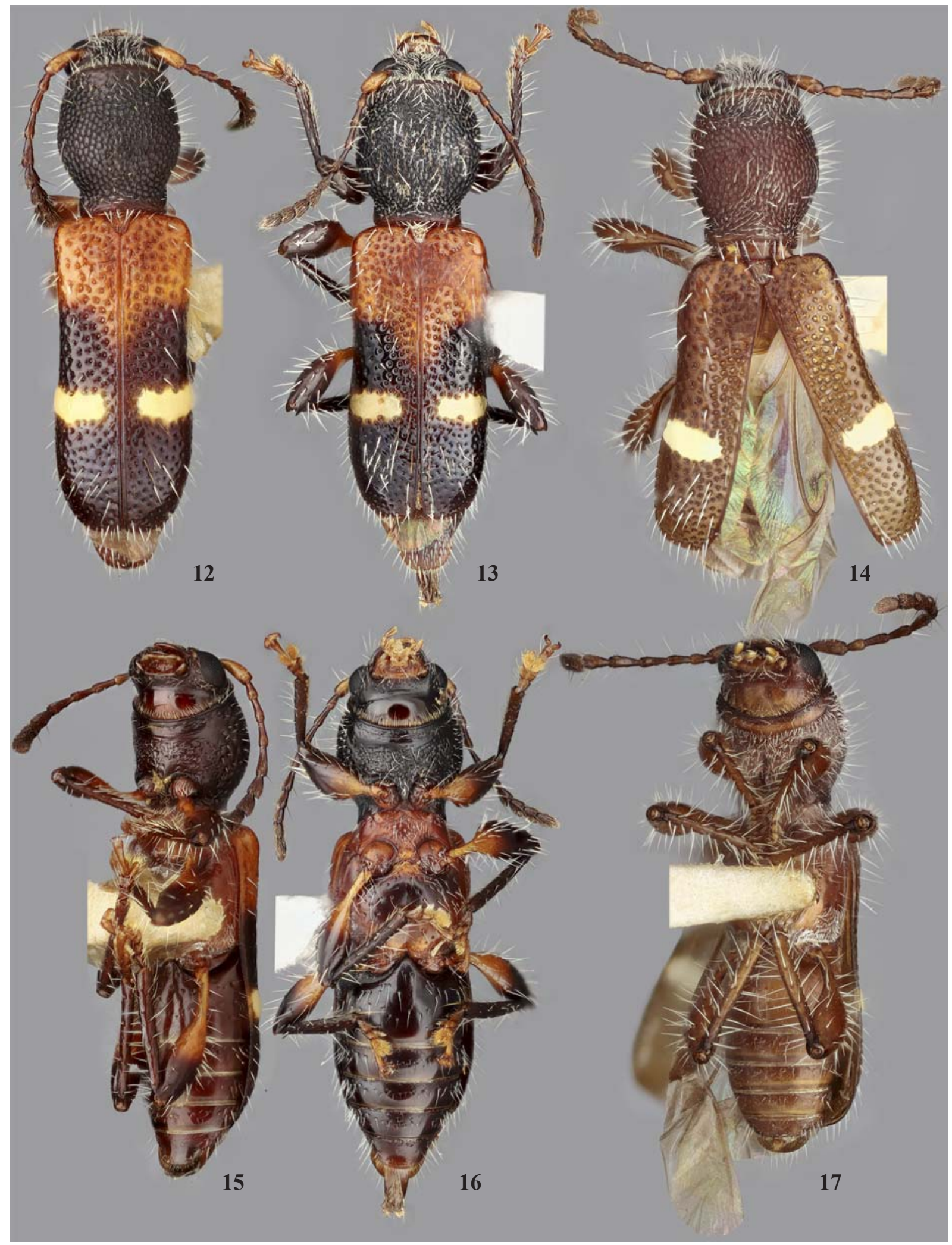

Figs 12-17. Calliclytus elegans comb.n., habitus (photographs by Alexander Konstantinov): 12, 15 - holotype, female; 13,16 - female from Puerto Rico; 14, 17 - holotype, male of Lamproclytus oakleyi Fisher, 1935; 12-14 - dorsal view; 15-17 - ventral view.

Рис. 12-17. Calliclytus elegans comb.n., общий вид (фотографии А. Константинова): 12, 15 — голотип, самка; 13,16 - самка из Пуэрто Рико; 14, 17 - голотип, самец Lamproclytus oakleyi Fisher, 1935; 12-14 - сверху; 15-17 — снизу. 


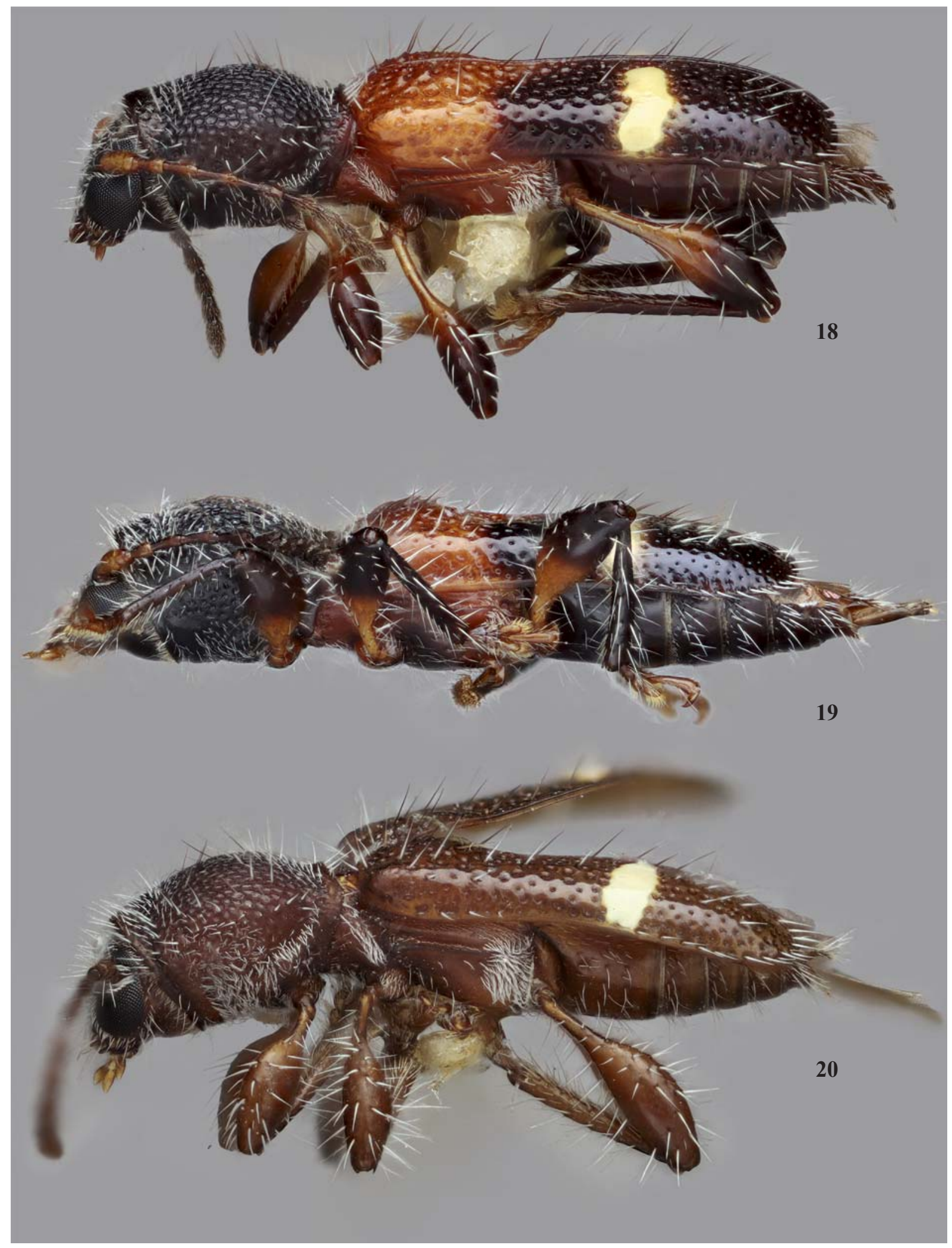

Figs 18-20. Calliclytus elegans comb.n., habitus, lateral view (photographs by Alexander Konstantinov): 18 — holotype, female; 19 female from Puerto Rico; 20 - holotype, male of Lamproclytus oakleyi Fisher, 1935.

Рис. 18-20. Calliclytus elegans comb.n., общий вид, сбоку (фотографии А. Константинова): 18 — голотип, самка; 19 - самка из Пуэрто Рико; 20 - голотип, самец Lamproclytus oakleyi Fisher, 1935. 


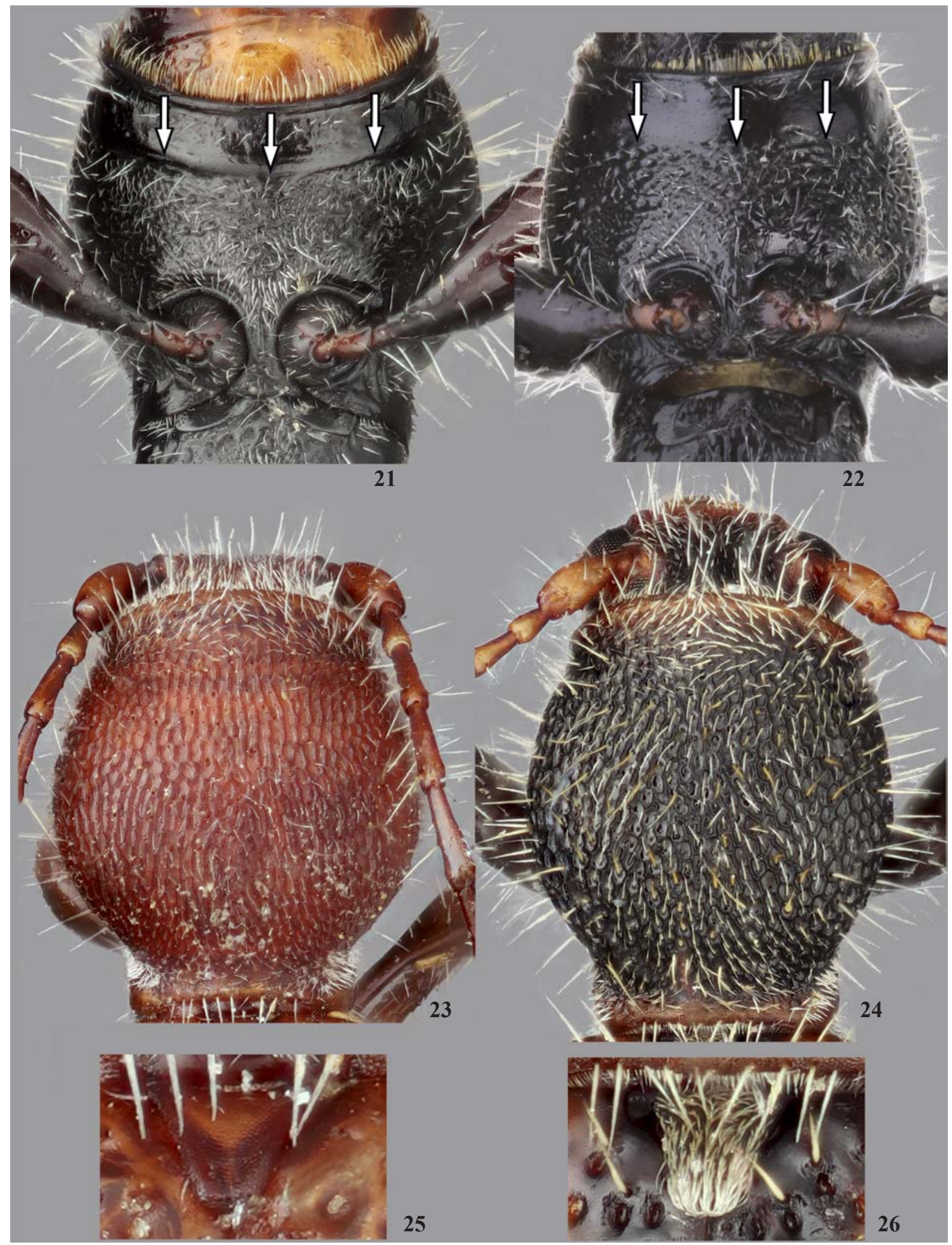

Figs 21-26. Calliclytus spp., holotypes: 21, 24, 26 - C. macoris, female; 22 - C. wappesi sp.n., female; 23,25 - C. schwarzi, male; 21-22 - prosternum; 23-24 - head and pronotum; 25-26 - scutellum (photographs by Alexander Konstantinov, except for figure 22). Рис. 21-26. Calliclytus spp., голотипы: 21, 24, 26 - C. macoris, самка; 22 - C. wappesi sp.n., самка; 23, 25 - C. schwarzi, самец; 21-22 - простернум; 23-24 - голова и переднеспинка; 25-26 - щиток (фотографии А. Константинова, за исключением рис. 22). 
Head short, with coarse dense punctures dorsally; antennal tubercles well-expressed; eyes moderately convex, with a very deep emargination, almost divided into upper and lower lobes, with evident, but not large ocelli; genae moderately short; frons barely convex; antennae short, 10 segmented (like in other congeners), freely reaching beyond base of elytra; length ratio of antennomeres $1-10,64: 28$ : $37: 44: 45: 39: 38: 30: 28: 30$; antennomeres $6-9$ distinctly serrate.

Pronotum clearly longitudinal, 1.13 times as long as width; with a sharp constriction in front of base, as in Fig. 3; apex 1.19 times as wide as base; on disc in middle part barely convex, but in basal third abruptly sloping down towards base, as in Fig. 9, coarsely alveolate-punctate, thereby cells/ alveoli round- and oval-shaped resembling that of $C$. macoris (Fig. 24) and C. elegans comb.n. (Fig. 27).

Scutellum small, strongly narrowed towards apex, triangular.

Elytra distinctly narrowed towards middle starting from base, then clearly widened in apical part, 2.15 times as long as wide at humeral width; on disc behind basal one fourth distinctly depressed, as in Fig. 9; with a coarse, mostly irregular, in places confluent puncturation being weakened near apex; each elytron with a relatively narrow fascia in

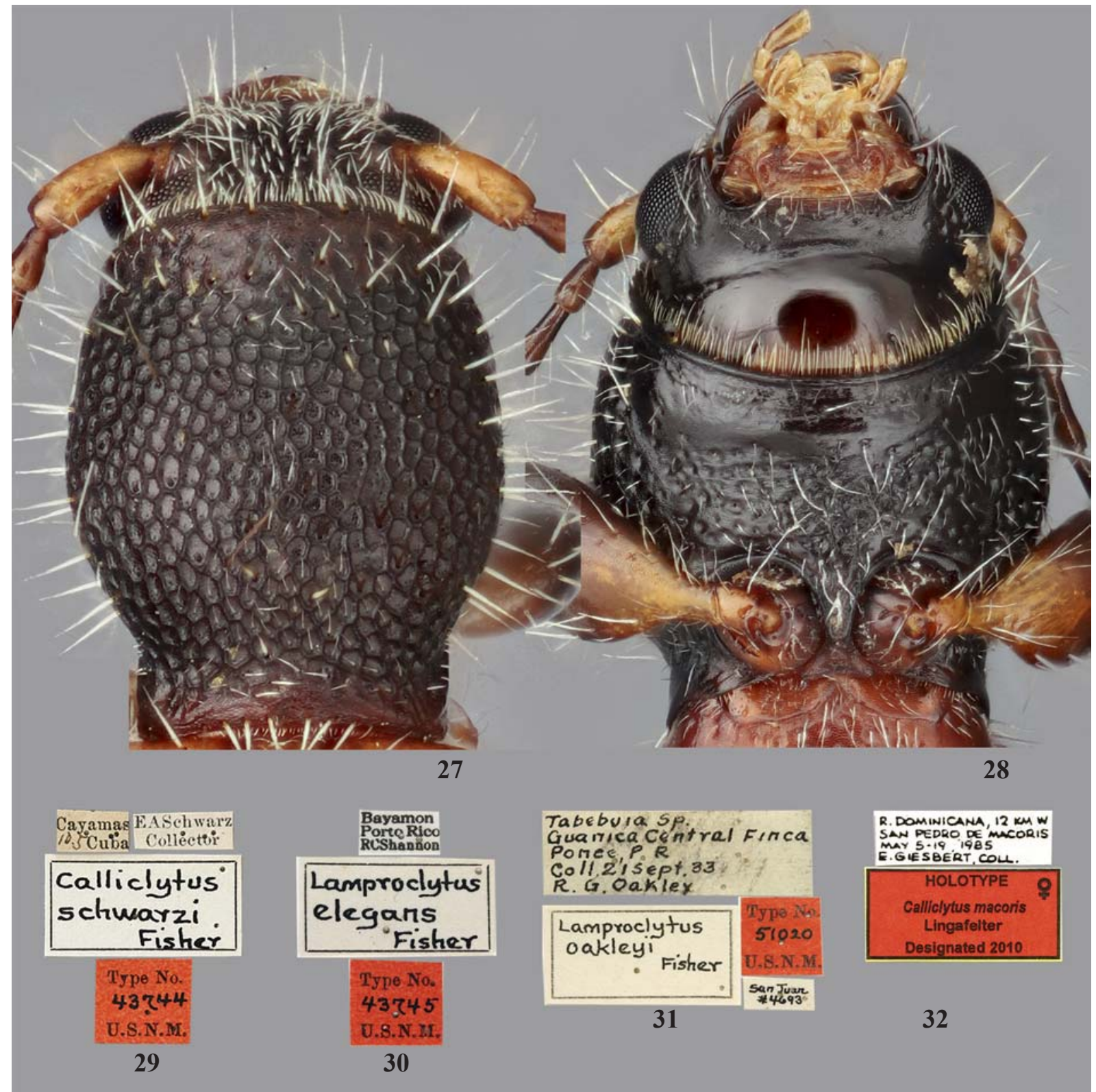

Figs 27-32. Calliclytus spp. (photographs by Alexander Konstantinov): 27-28, 30-31 - C. elegans comb.n. (27, 30 - holotype, female; 28 - female from Puerto Rico; 31 - holotype of Lamproclytus oakleyi); 29 - C. schwarzi, holotype; 32 - C. macoris, holotytpe; 27 head and pronotum; 28 - head and prosternum; 29-32 - labels.

Pис. 27-32. Calliclytus spp. (фотографии А. Константинова): 27-28, 30-31 - C. elegans comb.n. (27, 30 - голотип, самка; $28-$ самка из Пуэрто Рико; 31 - голотип of Lamproclytus oakleyi); 29 - C. schwarzi, голотип; 32 - C. тасогіs, голотип; 27 — голова и переднеспинка; 28 - голова и простернум; 29-32 - этикетки. 
front of the middle, being formed by an inflated surface, thereby a convex margin of fascia is located at its anterior border, as in Figs 3, 9; apical sutural angle obtuse, but wellexpressed.

Prosternum with numerous, rough, but shallow, irregular punctures, as in Fig. 22 (like in C. elegans comb.n., Fig. 28), with a very well-expressed, but not too sharp border between the scabrous and smoothened sculpture in its apical one fourth, as in Fig. 22 (like in C. elegans comb.n., Fig. 28); part of prosternum closing procoxal cavities posteriorly being narrow; prosternal process moderately narrow between coxae; mesosternum partly with coarse, irregular, grooves; mesosternal process between coxae much wider than prosternal process; metasternum and abdominal sternite with very sparse, predominantly rough punctures; metasternum long, about 1.5 times as long as mesosternum and slightly longer than first (visible) abdominal sternite, with distinct median suture except for about anterior one fourth; first (visible) abdominal sternite longest, but clearly shorter than all following (visible) sternites combined; last (visible) abdominal sternite widely rounded apically.

Legs short; femora strongly claviform; metatarsomere 1 distinctly shorter than two next metatarsomeres combined.

ETYMOLOGY. I am pleased to dedicate this magnificent new species to my colleague and longtime friend, Mr. James E. Wappes (American Coleoptera Museum, San Antonio, Texas, USA), who collected the holotype and has repeatedly provided a very important assistance to my research.

DISTRIBUTION. Dominican Republic.

REMARKS. Previously [Miroshnikov, 2014: 202], the sex of this specimen was misspelled as "male" due to a misprint. In addition, for some technical reasons, the pictures of specimen in publication under consideration [see page 202, figs 7-9 ] turned out to be slightly more narrowed than in reality in the original photographs presented here.

\section{Calliclytus elegans (Fisher, 1932), comb.n.} Figs 12-20, 27-28, 30-31.

Lamproclytus elegans Fisher, 1932: 68. Type locality: Puerto Rico, Bayamon (according to the original description and the label of the holotype). Wolcott, 1936: 261; Blackwelder, 1946: 583; Wolcott, 1951: 340; Chemsak et al., 1992: 73; Monné, 1993: 73; Monné, Giesbert, 1995: 124; Lingafelter, Micheli, 2004: 50; Monné, 2005: 552; Monné, Hovore, 2005: 134; Monné et al, 2007: 140; Micheli, 2010: 136, 137, fig.; Monné, Bezark, 2011: 171; Monné, 2012: 53; Bezark, Monné, 2013: 176; Lingafelter et al., 2014: 56, figs 60 i, j (holotype); Bezark, 2016 : 179; Monné, 2020: 827.

Lamproclytus oakleyi Fisher, 1935: 52. Type locality: Puerto Rico, Guanica Central Finca, Ponce (according to the original description and the label of the holotype). Wolcott, 1936:261; Blackwelder, 1946: 583; Wolcott, 1951: 340; Chemsak et al., 1992: 73; Monné, 1993: 73; Monné, Giesbert, 1995: 124; Micheli, Hovore, 2003: 1 (syn. pro L. elegans); Lingafelter et al., 2014: 109, figs $120 \mathrm{c}, \mathrm{d}$ (holotype; as syn. of L. elegans).

MATERIAL. Holotype + (USNM) (Figs 12, 15, 18), "Bayamon, Porto Rico, RCShannon", "Lamproclytus elegans Fisher", "Type No. 43745 U.S.N.M." (Fig. 30); holotype of L. oakleyi, $\mathrm{O}^{\prime}$ (USNM) (Figs 14, 17, 20), "Tabebuia sp., Guanica Central Finca, Ponce, P R [Puerto Rico], Coll. 21 Sept. [19]33, R.G. Oakley", "Lamproclytus oakleyi Fisher", "Type No. 51020 U.S.N.M.", "San Juan O 4693" (Fig. 31); 1 ( (USNM) (Figs 13, 16, 19), Puerto Rico: Guánica For. Trial near Headquarters, $17^{\circ} 58^{\prime} 49^{\prime \prime} \mathrm{N}, 66^{\circ} 51^{\prime} 74^{\prime \prime} \mathrm{W}$, 11-12 June 2002 Beating vegetation, leg. Steven W. Lingafelter, Lamproclytus elegans Fisher Det. S. Lingafelter, 2002; 19 (EMEC) (photograph), Puerto Rico.

DISTRIBUTION. Puerto Rico.

\section{Key to SPECIES OF CALLICLYTUS}

1. Eburneous fascia on each elytron is located in front of the middle, as in Figs 1-3, 7-9 2

- Eburneous fascia on each elytron is located in front of apical third, thereby elytra in about basal third reddish brown or entirely brown (excluding an eburneous fascia), as in Figs 12-14, 18-20 .................... C. elegans (Fisher), comb.n.

2. Elytra in about basal third entirely or predominantly reddish brown, as in Figs 1-2, 7-8; head entirely or at least ventrally brownish red, as in Figs 1-2, 4-5, 23-24 ..... 3

- Elytra (excluding an eburneous fascia and a brownish apical spot at suture) entirely black, as in Figs 3, 9; head entirely black, as in Figs 3, 6 ............. C. wappesi sp.n.

3. Prothorax, meso- and metasternum black, as in Figs 2, 5, 8, 21, 24; pronotal disc entirely sharply alveolate-punctate, thereby cells round- and oval-shaped, as in Fig. 24; scutellum with a dense, recumbent, white setation, as in Fig. 26; elytra in about basal third predominantly reddish brown, on sides of scutellum and behind it black, and with a light spot apically, as in Fig. 2 ................. C. macoris Lingafelter

- Prothorax, meso- and metasternum brownish red, as in Figs 1, 4, 7, 23; pronotal disc mostly with coarse, broken, longitudinal, irregular, narrow, strongly and very strongly elongate, predominantly well-expressed cells and only partly with oval and roundish cells, as in Fig. 23; scutellum glabrous, as in Fig. 25; elytra in about basal third entirely reddish brown, without light spot apically, as in Fig. 1 ...................... C. schwarzi Fisher

Acknowledgements. I am very grateful to James E. Wappes (American Coleoptera Museum, San Antonio, Texas, USA) for the opportunity to study the very valuable material he collected in the Dominican Republic, to Alexander S. Konstantinov (USNM) for the helpful provision of a series of high-quality photographs of Calliclytus specimens, to Steven W. Lingafelter (APHIS-PPQ-USDA, Douglas, Arizona, USA), Eugenio H. Nearns (National Identification Services, Smithsonian Institution, Washington, D.C., USA), Gérard L. Tavakilian (Muséum national d'Histoire naturelle, Paris, France), Lyubomir Penev and Tanya Kolibarova (Pensoft Publishers, Sofia, Bulgaria), again to Alexander S. Konstantinov and James E. Wappes for having helpfully shared some valuable information used in the present paper. I give special thanks to Kirill V. Makarov (Moscow Pedagogical State University, Moscow, Russia) for having rendered his great help in the preparation of pictures of the holotype of a new species described here and to my wife Tatiana P. Miroshnikova who helped a lot in the preparation of the illustrations for publication.

\section{References}

Bezark L.G. 2016. Checklist of the Oxypeltidae, Vesperidae, Disteniidae and Cerambycidae, (Coleoptera) of the Western Hemisphere. 497 pp. Available from: https://www.zin.ru/Animalia/ Coleoptera/Rus/whemis16.htm

Bezark L.G., Monné M.A. 2013. Checklist of the Cerambycidae and related families (Coleoptera) of the Western Hemisphere 2013 Version. 484 pp. Available from: https://www.zin.ru/Animalia/ Coleoptera/rus/allpdf16.htm

Blackwelder R.E. 1946. Checklist of the coleopterous insects of Mexico, Central America, the West Indies and South America. Part 4 // Bulletin of the United States National Museum. No.185. P.551-763.

Chemsak J.A., Linsley E.G., Noguera F.A. 1992. II. Los Cerambycidae y Disteniidae de Norteamérica, Centroamérica y las Indias 
Occidentales (Coleoptera). Instituto de Biología, Universidad Nacional Autónoma de México. Listados Faunísticos de México. 204 pp.

Devesa S., Fonseca E., Barro A. 2015. Longicornios de Cuba (Coleoptera: Cerambycidae). Vol.1. Parandrinae, Prioninae, Spondylidinae, Cerambycinae. Greta Editores. 353 pp.

Fisher W.S. 1932. New West Indian Cerambycid beetles // Proceedings of the United States National Museum. Vol.80. No.2922. Art.22. P.1-93.

Fisher W.S. 1935. New Cerambycid beetles from Puertto Rico // The Journal of Agriculture of the University of Puerto Rico. Vol.19. No.2. P.51-63.

Lingafelter S.W. 2011. New myrmecomorphous longhorned beetles from Haiti and the Dominican Republic with a key to Anaglyptini and Tillomorphini of Hispaniola (Coleoptera, Cerambycidae, Cerambycinae) // ZooKeys. No.106. P.55-75. doi: 10.3897/zookeys.106.1470.

Lingafelter S.W., Micheli J. 2004. New species of Cerambycidae (Coleoptera) from Puerto Rico with records and notes for other species // Journal of the New York Entomological Society. Vol.112. No.1. P.37-55.

Lingafelter S.W., Nearns E.H., Tavakilian G.L., Monné M.A., Biondi M. 2014. Longhorned woodboring beetles (Coleoptera: Cerambycidae and Disteniidae): primary types of the Smithsonian Institution. Washington D.C.: Smithsonian Institution Scholarly Press P. v-xviii + 1-110 + [111-290 with figs 8-187] + 291-390.

Micheli J.A. 2010. Longicornios de Puerto Rico (Coleoptera: Cerambycidae). Pensoft Publishers. 298 pp.

Micheli J., Hovore F.T. 2003. New synonymies and distributional records for Caribbean Cerambycidae (Coleoptera) // The Coleopterists Bulletin. Vol.57. No.1. P.1-4

Miroshnikov A.I. 2014. A review of the genus Clytellus Westwood 1853 , with notes on its systematic position and descriptions of eleven new species (Coleoptera: Cerambycidae). P.133-237 // Konstantinov A.S., Ślipiński S.A., Solodovnikov A.Yu. (eds.). Advances in studies on Asian cerambycids (Coleoptera: Cerambycidae). Papers by Alexandr I. Miroshnikov, dedicated to the memory of Dr. Judson Linsley Gressitt. Krasnodar-Moscow: KMK Scientific Press Ltd. 237 pp.

Monné M.A. 1993. Catalogue of the Cerambycidae (Coleoptera) of the western hemisphere. Part IX. Subfamily Cerambycinae:
Tribes Clytini, Anaglyptini, Tillomorphini and Cleomenini // Sociedade Brasileira de Entomologia. Vol.9. P.1-131.

Monné M.A. 2005. Catalogue of the Cerambycidae (Coleoptera) of the Neotropical Region. Part I. Subfamily Cerambycinae // Zootaxa. Vol. 946. P. 1-765.

Monné M.A. 2012. Catalogue of the type-species of the genera of the Cerambycidae, Disteniidae, Oxypeltidae and Vesperidae (Coleoptera) of the Neotropical Region // Zootaxa. Vol.3213. P.1-183.

Monné M.A. 2020. Catalogue of the Cerambycidae (Coleoptera) of the Neotropical Region. Part I. Subfamily Cerambycinae. 1122 pp. Available from: https://cerambycids.com/catalog/

Monné M.A., Bezark L.G. 2011. Checklist of the Cerambycidae and related families (Coleoptera) of the Western Hemisphere 2011 Version. 469 pp. Available from: https://www.cerambycoidea. com/papers.asp.

Monné M.A., Bezark L.G., Hovore F.T. 2007. Checklist of the Cerambycidae, or longhorned beetles (Coleoptera) of the Western Hemisphere. 417 pp.

Monné M.A., Giesbert E.F. 1995. Checklist of the Cerambycidae and Disteniidae (Coleoptera) of the Western Hemisphere. Burbank: Wolfsgarden Books. xiv +419 pp.

Monné M.A., Hovore F.T. 2005. Electronic Checklist of the Cerambycidae of the Western Hemisphere. $132 \mathrm{pp}$.

Peck S.B. 2005. A checklist of the beetles of Cuba with data on distributions and bionomics. (Insecta: Coleoptera) // Arthrropods of Florida and neighboring land areas. Vol.18. P. [1-8]+1-241.

Peck S.B., Perez-Gelabert D.E. 2012. A summary of the endemic beetle genera of the West Indies (Insecta: Coleoptera); bioindicators of the evolutionary richness of this Neotropical archipelago // Insecta Mundi. No.0212. P.1-29.

Wolcott G.N. 1936. "Insectae Borinquensis". A revised annotated check-list of the insects of Porto Rico, with descriptions of some new species // The Journal of Agriculture of the University of Puerto Rico. Vol.20. P.1-627.

Wolcott G.N. 1951. The insects of Puerto Rico. Coleoptera // The Journal of Agriculture of the University of Puerto Rico. Vol.32 (1948). No.2. P.225-416.

Zayas F. 1975. Revision de la familia Cerambycidae (Coleoptera, Phytophagoidea). Havana: Academia de Ciencias de Cuba, Instituto de Zoologia. 443 pp. 